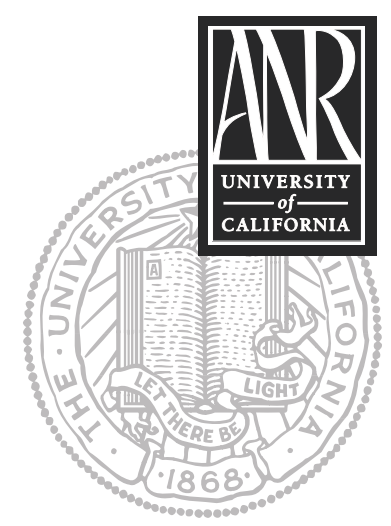

UNIVERSITY OF CALIFORNIA

Division of Agriculture and Natural Resources http://anrcatalog.ucdavis.edu

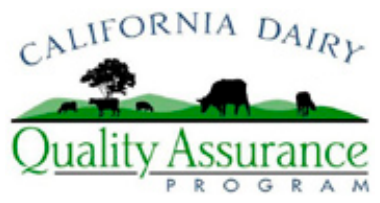

University of California in Partnership with the California Dairy Quality Assurance Program, http://www.cdqa.org

California Dairy Water Quality Compliance Guide A water quality and technical assistance program for California dairy operators

This publication is part of the California Dairy Water Quality Compliance Guide, a series developed for California dairy operators in response to the adoption of waste discharge requirements (WDR). The goal of the series is to provide information to assist producers in developing and implementing waste and nutrient management plans.

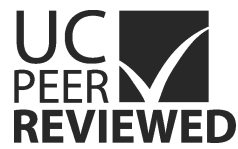

\title{
How To Improve Your Preliminary Dairy Facility Assessment Ratio
}

DEANNE MEYER, Livestock Waste Management Specialist, University of California, Davis; JOHN MENKE, California State Water Resources Control Board

This publication briefly describes opportunities for dairy operators to improve facility nutrient balance based on the results of the preliminary dairy facility assessment (PDFA).
In May 2007, the Central Valley Regional Water Quality Control Board (the "Regional Board") adopted Waste Discharge Requirements General Order No. R5-2007-0035 for Existing Milk Cow Dairies (the "General Order"), which includes requirements for manure management practices. (See Order No. R5-2007-0035, Waste Discharge Requirements for General Order for Existing Milk Cow Dairies, May 3, 2007; http:// www.waterboards.ca.gov/centralvalley/adopted_orders/GeneralOrders/R5-2007-0035. pdf.) One of the first items for producers to complete is a preliminary dairy facility assessment (PDFA), which is due December 31, 2007.

\section{PRELIMINARY DAIRY FACILITY ASSESSMENT}

In the past, producers and regulators alike have relied on rules of thumb to determine whether there is sufficient land at a given dairy to use nutrients excreted by cows. These "cows per acre" rules of thumb were developed in the early 1970s based on estimates of nitrogen excreted by animals and estimates of nitrogen taken up by crops. Adjustments were made if large quantities of manure were removed from the facility and associated farmland.

Cows produce much more milk today than they did in the 1970s. This requires more nutrient intake (a higher quality and quantity of feed) and results in more nutrients excreted in manure. It also means that the old rules of thumb are no longer appropriate.

The objective of the PDFA required by the General Order is to make a preliminary evaluation of both the nutrient balance and the wastewater storage capacity of each dairy. The electronic PDFA tool (see http://www.co.merced.ca.us/ EnvironmentalHealthWM) considers the major sources of nutrients potentially present for land application (animal manure, bedding, purchased fertilizers, and an assumed atmospheric deposition of nitrogen) and nutrient use (manure exports and crop use). The PDFA does not include nutrient inputs from the milking parlor, cow cooling, or irrigation water sources, since farm-specific data may not be available at this time. Nutrients in animals purchased or sold are also not calculated. The PDFA does not account for nutrients lost to the environment through leaching.

The PDFA is a valuable tool for providing a broad-brush analysis of the nutrient balance at a dairy. Evaluation of nitrogen $(\mathrm{N})$ and phosphorus $(\mathrm{P})$ balances should identify the relative degree of changes needed to achieve nutrient balance at a dairy. 


\section{WHAT VALUES DO I WANT TO REVIEW?}

Nitrogen and phosphorus are the two most important nutrients to review initially. As calculated in the PDFA,

$$
\begin{gathered}
\text { whole farm nitrogen balance }= \\
(\mathrm{N} \text { stored }+\mathrm{N} \text { imported }+ \text { atmospheric } \mathrm{N}-\mathrm{N} \text { exported }) \div \text { total } \mathrm{N} \text { removed by crops }
\end{gathered}
$$

where $\mathrm{N}$ stored is calculated as $\mathrm{N}$ excreted minus atmospheric losses of $\mathrm{N}$ (assumed to be $30 \%$ ). An example of potential results from four dairies is shown in figure 1 .

If the whole farm nitrogen balance is greater than 1.65 , a review must be made of nitrogen inputs and outputs at the facility to identify how to reduce inputs, increase outputs, or both. The greater the balance ratio, the more urgent the need to make major improvements. The operator must also create a "Proposed Interim Facility Modifications as Necessary to Balance Nitrogen" and submit it to the Central Valley Regional Water Quality Control Board with the first annual report, due July 1, 2008. Documentation that these modifications have been completed is required to be submitted by July 1, 2009.

Similarly,

phosphorus balance $=(\mathrm{P}$ stored $[$ i.e., excreted $]+\mathrm{P}$ imported $-\mathrm{P}$ exported $) \div$ total $\mathrm{P}$ removed by the crop

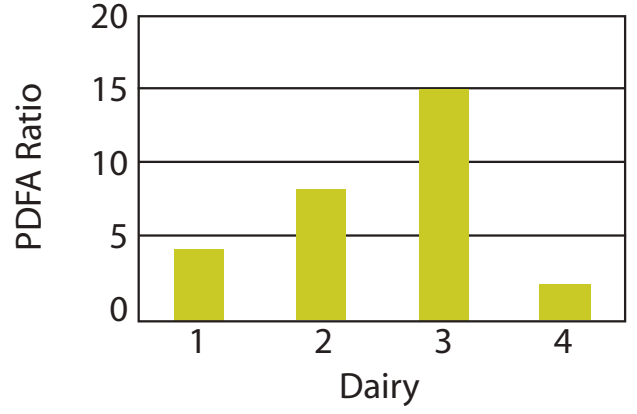

Figure 1. Preliminary dairy facility assessment results for four dairies.
If the phosphorus balance is positive ( $>1$ ), a review of phosphorus inputs and outputs should be made to identify practices that can be modified to improve the balance. There is no current regulatory requirement for submission of documentation to improve phosphorus balance.

The method used to estimate nitrogen and phosphorus excretion is assumed to be within 20 percent of actual excretion values. Estimated nitrogen excreted will be an underestimate of actual nitrogen excreted when animals are fed higher concentrations of crude protein. If this is the case, the actual whole farm nitrogen balance ratio will be greater than the calculated ratio. In the PDFA, the contributions of nitrogen and phosphorus in fresh water and irrigation water supply sources are not considered. These will be considered in the annual dairy facility assessments beginning in July 2008, when farm-specific data are available.

\section{HOW DO I IMPROVE MY RATIOS?}

The PDFA calculation does not consider all nutrient sources. If balance ratios are relatively close to the upper acceptable limit for nitrogen (1.65), an operator may want to consider whether additional nitrogen inputs from fresh water and irrigation water sources are likely to significantly change the whole farm nitrogen balance. When the balance exceeds 1.65, major modifications at the facility must be made to improve nitrogen management. The greater the balance ratio (over 1.65), the more extensive the necessary modifications must be. In many cases, a combination of several modifications may be the most effective way to achieve whole farm balance.

There are two basic methods to modify nutrient balances:

- Reduce inputs: Reduce the amount of nutrients generated .

- Increase outputs: Increase the amount of nutrients harvested or used from crops.

These two practices are discussed below. Advanced treatment technologies for manure solids or process wastewater are not discussed in this publication. Other publications will quantify nutrient changes resulting from these technologies. 


\section{Input Modification: Reducing Nutrients Generated}

Modify dietary intake to reduce excretion of nitrogen and phosphorus by reducing feed imports Consult with a nutritionist to ensure that crude protein and phosphorus concentrations in animal diets meet production goals and minimize nutrient excretion. In some cases a diet to reduce excretion may cost a little more. However, managing diet is often the least-expensive way to reduce nutrient generation at a facility. It is also a critical control point to reduce salt generation.

\section{Alter bedding strategies}

Reduce importation of nutrients in the form of bedding when possible. Use the manure with the lowest nutrient value when solid manure is used as bedding in free-stall facilities. This will minimize the transfer of nutrients and salts from the solid manure (bedding) to the liquid wastewater storage system.

\section{Reduce fresh water use in the milking process}

Reduction in fresh water use can reduce nitrogen and salt loading of the waste stream in areas where groundwater has elevated nitrogen and salt concentrations. Be sure that any modifications in water use are done with recognition of the impact on liquid manure handling systems and the ability to apply liquid manure to the land.

\section{Implement a nutrient management plan}

Plan to use nutrients in manure effectively and reduce the use of purchased fertilizers.

\section{Reduce herd size}

Relocate animals (calves, heifers, and dry stock) away from the dairy to improve the nutrient balance at the facility. If there is a large nutrient imbalance, it may be necessary to reduce the milk herd (number of lactating cows) to achieve an acceptable balance.

\section{Output Modification: Increasing Manure Exports or Nutrients Harvested in Crops}

\section{Increase exports of manure nutrients}

Physical removal of manure from the dairy operation reduces the need to land apply the material. This may include using an advanced manure treatment technology to reduce manure volume (increasing the nutrient density of the finished product) and transporting it off-site.

\section{Alter cropping practices}

Growing an additional or alternate crop (changing cultivars, crop type, or cropping frequency) can significantly improve nutrient balance by increasing the uptake of nutrients at the dairy. Changing cropping practices to improve yields or otherwise increase nutrient uptake can also be helpful. Based on the General Order, the total nitrogen applied cannot exceed 1.4 to 1.65 times the amount of nitrogen removed by the crop.

\section{Improve accessibility to cropland}

Ensuring that all cropland can receive manure reduces the need to import fertilizer. Some facilities have sufficient farmland to use nutrients in manure but lack infrastructure to get the manure to the fields. Investment in roads, trucks, pipelines, and so on may increase the ability to use nutrients at a facility and minimize nutrient imbalance.

\section{Export crops from the dairy}

If crops are grown that are not consumed by animals and potentially have higher nutrient removal rates, there may be an opportunity to export them (and their associated 
nutrients) off-site. Exporting crops removes the nutrients from the facility and reduces imbalance.

\section{Acquire more cropland}

Adding land (either through direct purchase, renting or leasing, or owner agreement) may provide an opportunity to use greater amounts of manure. However, acquiring additional land may not be feasible due to high cost or other issues. If additional land is available be sure it can receive nutrients in compliance with the General Order. Acquiring land that already has too much nitrogen or phosphorus does not increase land available for manure application.

\section{Improve efficiency of nutrient incorporation into milk production or milk composition without adding additional nutrients to the diet}

Theoretically, this would reduce the amount of nutrients excreted in manure and increase the amount of nutrients removed from the facility in animal product.

\section{CONCLUSION}

If the PDFA shows that the whole farm nitrogen balance exceeds 1.65, changes must be made to protect underlying groundwater and nearby surface waters to be in compliance with the General Order. The type and magnitude of changes necessary depends on the individual facility, situation, and PDFA values. Interim modifications are required to be made by July 1, 2009. At that time, a nutrient management plan, which includes a retrofitting plan, must be created to describe how the facility nitrogen balance will be improved. Facility modifications and alterations must be completed by July 1, 2012.

Potential changes that can be made in the waste management program include reducing nutrient inputs, increasing managed outputs, and increasing nutrient exports.

\section{RESOURCES}

California Dairy Quality Assurance Program Web site, http://www.cdqa.org.

Koelsch, R. Whole farm nutrient planning. Lesson 2. Livestock and poultry environmental stewardship curriculum. LEPS Web site, http://www.lpes.org.

Meyer, D., J. Menke, W. Powers, and J. P. Harner III. 2005. Manure nutrient export strategies. Proceedings of the 7th Western Dairy Management Conference. WDMC Web site, http://www.wdmc.org/2005/17Meyer.pdf.

\section{ACKN OWLEDGMENTS}

Series editors Denise Mullinax, Assistant Manager California Dairy Quality Assurance Program; Deanne Meyer, Livestock Waste Management Specialist, Department of Animal Science; and Patricia Price, Staff Research Associate, Department of Animal Science, University of California, Davis. Technical reviews provided by Regional Water Quality Control Board 5 Confined Animal Facility Staff; USDA Natural Resources Conservation Service; the State Water Resources Control Board; and the California Department of Food and Agriculture and Western United Dairymen.

Financial support was provided by grants from the California Dairy Research Foundation, US EPA (Agreement 9-101-250-0), and the State Water Resources Control Board (Grant number 05-095-550-0). The contents of this publication do not necessarily reflect the views and policies of the US EPA, SWRCB, or RWQCB, nor does mention of trade names or commercial products constitute endorsement or recommendation for use. Should any information here conflict with the General Order or official information provided by the Regional Board, the General Order and/or information provided by the Regional Board takes precedence. 


\section{FOR FURTHER INFORMATION}

To order or obtain printed ANR publications and other products, visit the ANR Communication Services online catalog at http://anrcatalog.ucdavis.edu. You can also place orders by mail, phone, or FAX, or request a printed catalog of our products from:

\section{University of California}

Agriculture and Natural Resources

Communication Services

6701 San Pablo Avenue, 2nd Floor

Oakland, California 94608-1239

Telephone: (800) 994-8849 or (510) 642-2431

FAX: (510) 643-5470

E-mail inquiries: danrcs@ucdavis.edu

An electronic version of this publication is available on the ANR Communication Services Web site at http://anrcatalog.ucdavis.edu.

Publication 8283

ISBN-13: 978-1-60107-527-7

C2007 The Regents of the University of California

Division of Agriculture and Natural Resources

All rights reserved.

No part of this publication may be reproduced, stored in a retrieval system, or transmitted, in any form or by any means, electronic, mechanical, photocopying, recording, or otherwise, without the written permission of the publisher and the authors.

The University of California prohibits discrimination or harassment of any person on the basis of race, color, national origin, religion, sex, gender identity, pregnancy (including childbirth, and medical conditions related to pregnancy or childbirth), physical or mental disability, medical condition (cancer-related or genetic characteristics), ancestry, marital status, age, sexual orientation, citizenship, or status as a covered veteran (covered veterans are special disabled veterans, recently separated veterans, Vietnam era veterans, or any other veterans who served on active duty during a war or in a campaign or expedition for which a campaign badge has been authorized) in any of its programs or activities. University policy is intended to be consistent with the provisions of applicable State and Federal laws.

Inquiries regarding the University's nondiscrimination policies may be directed to the Affirmative Action/Staff Personnel Services Director, University of California, Agriculture and Natural Resources, 1111 Franklin Street, 6th Floor, Oakland, CA 94607-5201, (510) 987-0096. For information about ordering this publication, telephone 1-800-994-8849.

This publication has been anonymously peer reviewed for technical accuracy by University of California scientists and other qualified professionals. This review process was managed by the ANR Associate Editor for Animal, Avian, and Aquaculture Sciences.

pr-12/07-SB/CM 